\title{
Inconsistent Verdicts and the Possibility of Innocence:
}

\section{A Comment on $R v \boldsymbol{R} V$}

\author{
Christopher Sherrin \\ Associate Professor, Faculty of Law \\ Western University, Canada
}

\section{The Decision \\ II. The Problems \\ A. Systemic Issue \\ B. Setting the Bar Low}

III. Conclusion

A jury delivers inconsistent verdicts when, in a multi-count indictment, they render judgment that finds the accused guilty and not guilty of the same conduct. Why a jury would do this is open to multiple explanations. ${ }^{1}$ The jury could have been confused or mistaken about the evidence or the law. The jury could have decided to offer leniency to save an accused from what they consider to be an excessively harsh outcome (a form of partial jury nullification). Importantly, the jury also could have convicted for reasons that undermine the need for proof beyond a reasonable doubt. A jury, unable to achieve unanimity for either total acquittal or conviction, could have compromised and achieved unanimous support for a negotiated mix of convictions and acquittals, with some jurors acquiescing despite having a reasonable doubt. A jury, unpersuaded of guilt to the requisite degree, could also have convicted out of hostility, to punish an accused considered loathsome (even if not definitely a criminal). ${ }^{2}$

Any conviction in the face of reasonable doubt raises the risk of wrongful conviction. A reasonable doubt does not necessarily equate to proof of factual innocence, but it does establish legal innocence ${ }^{3}$ and at a minimum offers a warning signal that the accused may be innocent in a broader sense. The need for proof beyond a reasonable doubt must be scrupulously safeguarded in any system that seeks to avoid wrongful convictions.

\footnotetext{
${ }^{1}$ See Eric Muller, "The Hobgoblin of Little Minds? Our Foolish Law of Inconsistent Verdicts" (1998) 111 Harv L Rev 771 at 781-786, 796 [Muller].

${ }^{2}$ See ibid at 803-806. Muller discussed the possibility of jury hostility in the context of multi-accused cases, where one accused was potentially perceived as less worthy of the law's protection. His reasoning, however, can be applied to the case of a single accused facing multiple counts. The law has long been concerned about jurors convicting an accused because he is thought to be a bad man: see David Tanovich, Louis Strezos, and Casey Hill, McWilliams' Canadian Criminal Evidence, $5^{\text {th }}$ ed, loose-leaf (Carswell: Toronto, 2013-) at 5.20, 60.10.

${ }^{3}$ Grdic v The Queen, 1985 CanLII 34 (SCC), [1985] 1 SCR 810 at 825, online: 〈https://canlii.ca/t/1cxms>.
} 
In $R v R V,{ }^{4}$ the Supreme Court of Canada upheld convictions for two sexual offences in the face of an inconsistent acquittal for a third sexual offence. It did so by attributing the acquittal to the jury's understanding of an erroneous legal instruction that, it said, did not affect the convictions. The Court, in other words, purported to be able to divine the jury's reasoning and thereby make sense of the apparent inconsistency. The law has long allowed courts to dismiss an inconsistency by reference to how a jury could have evaluated the evidence. $R V$ conclusively established, for the first time, that it is also permissible to dismiss an inconsistency by reference to the jury's understanding of legal instructions.

The Court's analysis of the jury's reasoning might have been correct but ultimately it could be nothing more than a plausible guess that could discount the possibility of compromise or hostility. To make matters worse, the Court ignored reasons to think its guess was wrong, all while purporting to apply an exacting standard of proof. It did this in the context of legal rules that make it very hard to establish an inconsistent verdict in the first place. In the end, therefore, we are left with legal rules that concentrate more than ever on protecting the chance of a proper conviction rather than avoiding the risk of an improper one. This does not safeguard the need for proof beyond a reasonable doubt.

\section{The Decision}

RV was charged with three offences: sexual assault, sexual interference, and invitation to sexual touching. He was alleged to have sexually abused his partner's daughter when the daughter was between the ages of 7 and 13. The daughter was the only witness at trial. She testified to a variety of incidents in which RV had contact with her in circumstances of a sexual nature and seemingly for a sexual purpose.

If RV was guilty of one offence, he was guilty of the others. Given the age of the complainant and the details of the allegations, the evidence (if proven) satisfied the elements of all the offences. The charges were not particularized by time or in any other way that would have offered any basis for distinguishing between them. ${ }^{5}$

Despite this, the jury found RV not guilty of sexual assault but guilty of sexual interference and invitation to sexual touching. The Crown conceded that the verdicts were apparently inconsistent. ${ }^{6}$ Every judge in the Ontario Court of Appeal and Supreme Court agreed. ${ }^{7}$

The normal outcome of such a finding would either be an acquittal or a retrial on all counts. ${ }^{8}$ The majority of the Supreme Court, however, upheld the convictions for sexual interference and invitation to sexual touching. It also set aside the acquittal for sexual assault and stayed further proceedings on the charge.

\footnotetext{
${ }^{4} R v R V, 2021$ SCC 10 (CanLII), [2021] SCJ No 10 (QL), online: <https://canlii.ca/t/jdpb6> [RV SCC].

${ }^{5} R v R V, 2019$ ONCA 664 (CanLII) at para 5, online <https://canlii.ca/t/j23v5> [RV ONCA].

${ }^{6} R V$ SCC, supra note 4 at para 49.

${ }^{7} R V S C C$, ibid at paras 50, 81; RV ONCA, supra note 5 at paras 131-133, 152.

${ }^{8} R v$ Pittiman, 2006 SCC 9 (CanLII), [2006] 1 SCR 381 at para 14, online: 〈https://canlii.ca/t/1mv05> [Pittiman]; $R$ $v J F, 2008$ SCC 60 (CanLII), [2008] 3 SCR 215 at paras 38-42, online:<https://canlii.ca/t/21bgx >; R v Catton, 2015 ONCA 13 (CanLII), [2015] OJ No 184 at para 25, online: 〈https://canlii.ca/t/gfxxx >.
} 
The Court reached this unusual outcome by holding that it was able to discern the reasoning of the jury that led it to an apparently inconsistent and thereby unreasonable outcome. ${ }^{9}$ In the minds of the majority:

The jury mistakenly believed that sexual assault, but not the other two charges, required force beyond mere touching. As a result, the jury acquitted RV of sexual assault: they were not satisfied beyond a reasonable doubt that he applied force, in the colloquial sense, to the complainant. On the same evidence, they convicted the accused of sexual interference and invitation to sexual touching because they were satisfied that he touched the complainant in circumstances of a sexual nature. ${ }^{10}$

The majority explained that the jury was misled into thinking that the sexual assault charge required the use of force in the colloquial sense - that is, "physical strength, violence, compulsion, or constraint exerted upon or against a person"11 - by language in the jury charge and in documents given to the jury. Since the jury was not similarly misled on the other charges, the inconsistency between the verdicts was reconciled and the convictions on the sexual interference and invitation to sexual touching counts could be upheld. This marked the first time that a majority of Canada's highest court was willing to sustain a conviction, despite an apparently inconsistent acquittal, by reference to how a jury understood and applied the trial judge's instructions on the law.

\section{The Problems}

The majority's decision in $R V$ can be criticized for not being faithful to precedent or the strictures of the Criminal Code and for producing a result where the accused was technically found guilty and not guilty of the same conduct (on the basis that staying the sexual assault charge is, in law, tantamount to finding him not guilty). ${ }^{12}$ Here, however, I will focus on more substantive problems with the decision.

\section{A. A Systemic Issue}

The majority claimed that they knew why the jury decided as they did. Indeed, they claimed that they knew this with a high degree of certainty. ${ }^{13}$ But they could not actually know what the jury did. Juries deliberate in secret. They provide no explanation for their verdicts. Jury reasoning is invariably opaque. ${ }^{14}$

What the majority offered was a guess. It may have been an educated guess. It may have been a reasonable guess. It may have been a plausible guess. But it was ultimately a supposition. We can never know for certain what was in the minds of the jury members.

\footnotetext{
${ }^{9}$ When a jury delivers inconsistent verdicts, it necessarily acts unreasonably: RV SCC, supra note 4 at para 30.

${ }^{10} R V S C C$, ibid at para 66.

${ }^{11} R V S C C$, ibid at para 52.

12 These issues are discussed in the dissenting opinion of Justice Brown.

${ }^{13}$ RV SCC, supra note 4 at paras $65,69$.

${ }^{14}$ Muller, supra note 1 at 789.
} 
The majority correctly pointed out that appellate courts regularly consider the likely impact of jury instructions on a jury's reasoning and verdict when engaging in harmless error review. ${ }^{15}$ But what the majority failed to recognize is that appeals from inconsistent verdicts are not like most other appeals. In most cases, there is no reason to suspect that at least some members of the jury were not satisfied of the accused guilt; indeed, there is usually reason to believe the opposite. When verdicts are inconsistent, however, there is reason to suspect that members of the jury harboured doubts. We cannot know whether they actually did, but in a situation where innocence is a live possibility one must ask whether, from a systemic perspective, it is better to err on one side or the other The majority in $R V$ was willing to err on the side of safeguarding the possibility of a valid conviction. In a system that continues to uncover cases of wrongful conviction, ${ }^{16}$ it seems wiser to err on the side of safeguarding the possibility of a valid acquittal.

It is important to keep in mind that safeguarding the possibility of a valid acquittal does not necessarily spell the end of the story for the prosecution. An appellate court can order a retrial on all counts; indeed, the Supreme Court has said this is to be the usual remedy. ${ }^{17}$ A conviction, therefore, can still ultimately be obtained. The approach of the majority in $R V$, however, finalizes the story for the accused. He or she is denied the opportunity to have the outcome determined by a fresh jury, untainted by judicial error (or deadlock or hostility).

One must also consider the broader context of inconsistent verdict appeals. They often fail at the threshold stage of inconsistency. The appellant (who is almost always the accused) ${ }^{18}$ bears the onus to show that no reasonable jury whose members had applied their minds to the evidence could have arrived at the conclusion they did. This is recognized to be a "difficult" onus to meet. ${ }^{19}$ Apparently inconsistent verdicts can be reconciled on the basis that the strength of the evidence on counts differs, because the offences are temporally distinct, or because the proof of different charges depends on different witnesses. The appellant must demonstrate that, on any realistic view of the evidence, the verdicts cannot be reconciled on any rational or logical basis. ${ }^{20}$ The reality is that the system already strains to find reasons in the evidence to explain away an apparent inconsistency. Do we really need to protect the possibility of guilt so much that we should dare to assume we can know how a jury understood and applied the jury charge?

\section{B. Setting a Low Bar}

Perhaps the decision in $R V$ might be more palatable if the majority had truly been cautious before drawing conclusions about the reasoning of the jury. But, despite purporting to apply an exacting standard, the majority actually rested its conclusion on shaky grounds.

\footnotetext{
${ }^{15}$ RV SCC, supra note 4 at para 37.

${ }^{16}$ See, for example, the recent decision in $R v$ Hayman, 2021 ONCA 242 (CanLII), [2021] OJ No 1930, online: <https://canlii.ca/t/jfb3h>

${ }^{17}$ Pittiman, supra note 8 at para 14.

${ }^{18}$ The Crown usually has no interest in appealing inconsistent verdicts, except in response to an appeal by the accused. Inconsistent verdicts include at least one conviction and a guilty verdict on the remaining charges would have no effect on sentence.

${ }^{19}$ Pittiman, supra note 8 at para 7.

${ }^{20}$ Pittiman, ibid at paras 7-8.
} 
The majority held that the Crown can reconcile apparently inconsistent verdicts by showing, to a high degree of certainty, that 1) the acquittal was the product of a legal error in the jury instructions, 2) the legal error did not impact the conviction, and 3) the error reconciles the inconsistency by showing that the jury did not find the accused both guilty and not guilty of the same conduct. It is their reasoning on the first branch that is open to question.

As noted above, the majority found that the trial judge erroneously led the jury to believe that sexual assault requires more than touching, but rather the use of force in the colloquial sense. The Justices noted that, after instructing the jury that the application of "force" is required for sexual assault, the trial judge stated that for the other offences "touching" or an invitation to "touch" (for a sexual purpose) is required. They further noted that the trial judge twice mentioned that touching does not require force. This language and order of presentation could lead a jury to believe that force requires more than touching, but the trial judge also twice told the jury force includes any physical contact, even a gentle touch. In other words, the trial judge as often told the jury that force includes a gentle touch as she told them that touching does not require force. Combined, these instructions are confusing, but they do almost nothing to establish how the jury resolved the confusion. The majority of the Supreme Court relied on the fact of inconsistent verdicts to assume the jury followed one instruction and forgot or ignored the other This, at best, seems to offer weak circumstantial evidence - especially in a legal system that explicitly assumes jury members understand and apply the legal instructions they are given. ${ }^{21}$

The majority also relied on the fact that the trial judge gave the jury two documents (a verdict sheet and a decision tree) that told them to acquit of sexual assault if they did not find that RV intentionally applied force to the complaint and to find RV guilty of only simple assault if they found that RV intentionally applied force to the complaint but not in circumstances of a sexual nature. The majority explained that the "inclusion of simple assault in the decision tree and verdict sheet emphasized the difference between the use of the word 'force' for sexual assault and the use of 'touching' for the other two offences." 22 The repeated use of different terms can imply and even emphasize that there is a difference between them, but it says little if anything about the nature of the difference. The majority assumes that the jury would have concluded that there was a significant difference, whereas the jury could have concluded that the difference was relatively minor, as would be the case if force meant sustained contact whereas touching meant contact that was fleeting (i.e., that the difference rested on the length of contact rather than something else). This reasoning could have allowed the jury to rationalize why they were twice told that force includes a gentle touch but touching does not require force; a touch can be gentle yet sustained.

The majority also made much of the fact that the jury did not find RV guilty of simple assault. This indicated that the jury did not acquit of sexual assault because they were not satisfied that force was applied in circumstances of a sexual nature but because they were not satisfied that force was applied. This was, they said, the "rational inference." ${ }^{23}$ It is a rational inference, but it is

\footnotetext{
${ }^{21}$ See, e.g., R v NA, 2015 NWTCA 8 (CanLII), [2016] 1 WWR 677 at par 32, online: 〈https://canlii.ca/t/glvcp>; $R v$ Puddicombe, 2013 ONCA 506 (CanLII), [2013] OJ No 3507 at para 93, online: $\langle$ https://canlii.ca/t/fzzdt $>; R v$ Forknall, 2003 BCCA 43 (CanLII), [2003] BCJ No 108 (QL) at para 33, online: $\langle$ https://canlii.ca/t/5f23 >.

${ }^{22} R V$ SCC, supra note 4 at para 63.

${ }^{23} R V S C C$, ibid at para 68.
} 
not the only one. An alternative rational inference is that the jury acquitted because of a compromise verdict.

It is almost always possible to pick apart an argument. While I am inclined to think otherwise, perhaps all I have shown so far is that the majority might have erred. Even if that is so, there is an additional important reason to doubt that the majority got it right.

Implicit in the majority's judgment is the assumption that the jury would have found that the incidents of sexual abuse perpetrated by RV did not meet the colloquial definition of force: "physical strength, violence, compulsion, or constraint exerted upon or against a person." The evidence, however, makes that quite unlikely.

The complainant alleged that the abuse occurred over a period of six years. During that time, RV perpetrated a variety of different acts. Amongst others, RV held the complaint's hand and used it masturbate himself, pushed her head down towards his penis, and laid underneath her while one of them was unclothed and simulated intercourse, sometimes to the point of ejaculation. How could a jury find that none of those acts involved physical strength, compulsion, or constraint exerted upon or against the complainant? All of them would have involved substantial physical contact during a compelled interaction. Most of them would have involved extended - even lengthy - contact. Bodies were moving. Multiple body parts were involved. The complainant was literally pushed. All of this in the context where an adult seemingly in a quasi-parental relationship is imposing himself on a vulnerable pre-adolescent child.

The majority seems to be assuming that the jury in $R V$ understood force to require significant physical violence. That is possible, but it seems rather odd to think that a group of twelve citizens would all conclude that a person is not the recipient of force when she is placed on top of another person or made to move a part of her body in various ways.

The point of this is not to prove that the majority necessarily got it wrong. The point is not even to prove that the majority did not establish its conclusion to what is considered in law to be a high degree of certainty. The point is to raise the concern that in setting a precedent for what can amount to proof to a high degree of certainty, the majority in $R V$ set a low bar that could enable and encourage later courts to dismiss too easily the possibility of jury compromise or hostility of innocence - whenever they can contemplate something in the jury charge that could make sense of an apparently non-sensical verdict.

\section{Conclusion}

I do not know whether RV is factually innocent. I do not know why the jury in his case delivered the verdicts that it did. What I do know is that the verdicts they delivered are facially inconsistent and that this raises the real possibility that at least some members of the jury were not convinced of RV's guilt. The Supreme Court of Canada seemed too willing to ignore this possibility in order to safeguard the possibility that the entire jury thought he was guilty. 
Courts are already willing to dissect the reasoning behind inconsistent verdicts by reference to possible ways the jury might have viewed the evidence. Given what inconsistent verdicts can indicate, we should be hesitant to extend this by permitting another way to rationalize away inconsistency, this time by reference to how a jury understood and applied a confusing jury instruction. At a minimum, we should demand truly exacting proof of how a jury reasoned. This might come from something like a jury question that supplies direct evidence that the jury was thinking what we surmise it was thinking. ${ }^{24}$ On the other hand, maybe the best answer is not to surmise at all and just give both parties an opportunity to receive verdicts from a new jury who will (hopefully) give no indication that they may have convicted despite harbouring doubts about guilt.

\footnotetext{
${ }^{24}$ The jury in $R V$ asked about a contradiction between the verdict sheet and the decision tree regarding the availability of finding the accused guilty of simple assault rather than sexual assault: $R V$ SCC, supra note 4 at para 17 . There is no indication that the jury asked for a new definition of the word 'force' or for an explanation for the confusing definition previously provided.
} 